\title{
The Fate of Captive-bred Copper Pheasants Syrmaticus soemmerringii Released in Tochigi Prefecture, Eastern Japan
}

\author{
Noritomo Kawaji*, Yasuhiro Yamaguchi** and Yukihiro Yano*** 1)
}

\begin{abstract}
The fate of captive-bred Copper Pheasants Syrmaticus soemmerringii released in Tochigi Prefecture, eastern Japan, in order to restore the wild population, was investigated based on mark and recapture information, on hunting data and by radio tracking. From 1989 to 1997 , the recapture rate of all released individuals was $1.3 \%$. Most recovered Copper Pheasants were hunted within one hunting season after their release. Only $0.3 \%$ of all released individuals were recaptured beyond two hunting seasons. The extremely short longevity (average 11.4 days after release) of released birds was confirmed by radio tracking in Tochigi Prefectural Citizen's Park. Distances between release and recovery points averaged $14.6 \mathrm{~km}$, but some individuals moved more than 40 $\mathrm{km}$, and one $87 \mathrm{~km}$. Our results show that it is difficult to achieve population recovery using current methods. Based on our experience, we propose various improved release methods, including: changing the release points of males from refuges to hunting areas, and releasing females just before the breeding season.
\end{abstract}

Key words: Copper Pheasant, Fate after release, Hunting, Radio tracking, Recapture rate, Tochigi prefecture.

キーワード：ヤマドリ，放鳥後の運命，狩猟，ラジオトラッキング，回収率，栃 木県.

\section{Introduction}

The Copper Pheasant Syrmaticus soemmerringii is endemic to Japan, where it is found in three of four main Japanese islands, Honshu, Shikoku and Kyushu. It has long been prized by Japanese hunters as a good game bird (e.g. Yamashina 1976). Though the number of hunted Copper Pheasants has decreased dramatically since the 1970's, the causes of the decline are still unknown. About fifty thousand birds were shot in the recent hunting season, which is less than one tenth of the maximum number in the past time (Environmental Agency 2000). Shooting females of all subspecies and both sexes of one subspecies, ijimae, has been prohibited since 1975 and 1979, respectively. Furthermore, for the last 30 years local governments have been expanding bird protection areas such as refuges and seasonal hunting-prohibited areas. Therefore, only male birds in restricted areas have been shot by hunters recently. Nevertheless, many bird watchers and hunters have pointed out that the opportunities to see the Copper Pheasant in the wild have also

Received 26 Nov. 2001, Revised 16 May 2002, 2nd Revision 3 Sept. 2002, Accepted 9 Sept. 2002.

* Department of Wildlife Biology, Forestry and Forest Products Research Institute, P. O. Box 16, Tsukuba Norin, Ibaraki 305-8687, Japan. E-mail: kawajin@ffpri.affrc.go.jp

** Wildlife Management Laboratory, National Agricultural Research Center, National Agricultural Research Organization, Kannondai 3-1-1, Tsukuba, Ibaraki 305-8666, Japan. E-mail: yamay@affrc.go.jp

*** Tochigi Prefectural Citizen's Park Management Office, Nagai 2927, Yaita, Tochigi 329-2514, Japan.

1) Present address: Tochigi Prefectural Government Office, Hanawada 1-1-20, Utsunomiya, Tochigi 3208501, Japan. 
apparently decreased recently. The conservation status of this pheasant is now at the near threatened (NT) level by the criteria of the International Union for Conservation of Nature and Nature Resources (e.g. Fuller \& Garson 2000).

Since 1973, more than seven thousand raised birds have been released annually in mainly northern and central Japan in order to restore the natural population of the species (Environmental Agency 1975). In total, about one hundred thousand birds had been released up to 1998 in 30 prefectures (Environmental Agency 2000), including some remote islands off Honshu and Hokkaido that are not native areas of this species (e.g. Kawaji 1993, Hokkaido Institute of Environmental Science 1998). From 1973 to 1998, the largest number was released in Tochigi prefecture, eastern Japan, followed by Tokyo, Saitama, Akita and Chiba, respectively (Fig. 1). These releases were mainly conducted in refuge areas. One of the purposes of this was to allow the birds to breed without any hunting pressure so as to increase natural populations, and to allow their offspring to disperse over adjacent hunting areas. But the fate of the released birds has been investigated by only a few reports (e.g. Masubuchi \& Atsumi 1975, Dainippon Ryoyukai 1986).

In this paper, we show the fate of captive-bred Copper Pheasants released in the wild based on the recapture rates by hunters and radio tracking data in Tochigi Prefecture. We also examine problems with the release system in Japan from these analyses, and propose more effective methods to restore the natural populations of Copper Pheasants.

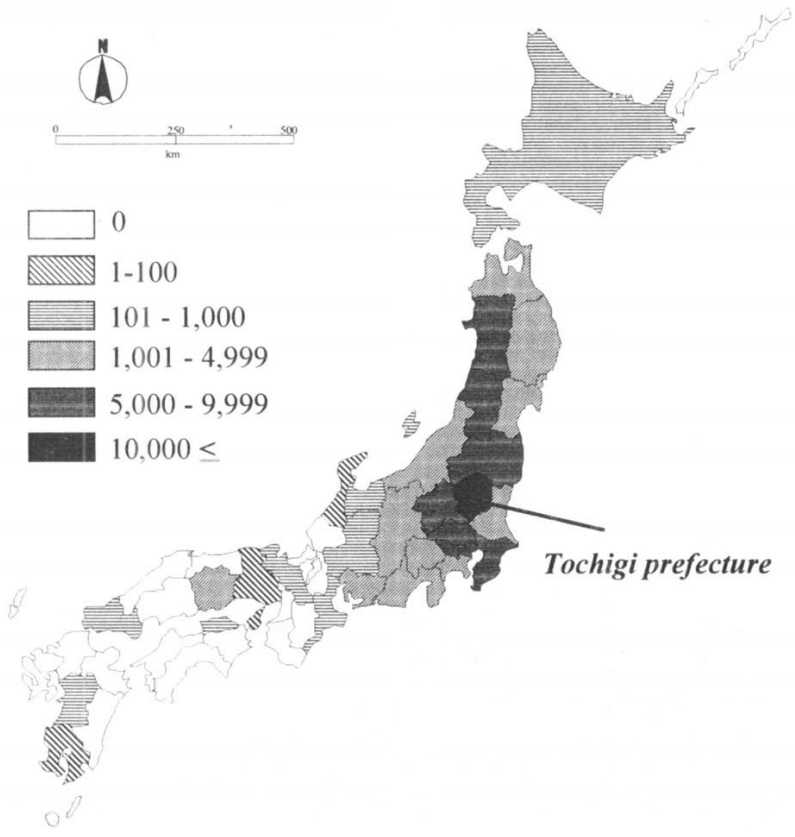

Fig. 1. Distribution of the total number of released Copper Pheasants in each prefecture from 1973 to 1998. 


\section{Study Area and Methods}

We used statistical data issued by Tochigi prefecture from 1989 to 1997 . During this period, 179-377 male Copper Pheasants had been released annually (2,670 in total) to refuges and seasonal hunting-prohibited areas between late October and early November just before the beginning of the regular hunting season. In the prefecture, a decline has also been occurring in annual number of hunted Copper Pheasants since the 1970's (Fig. 2). The legs of male birds have been attached with numbered aluminum rings before the release. We obtained information from rings brought back by hunters or from carcasses with rings to estimate the fate of released pheasants.

We calculated the success ratio between the number of hunters and hunted Copper Pheasants by referring to Leopold (1961). The recapture rates were calculated as the ratio of recaptured pheasants to the total number of birds released in a certain year. The mobility of released pheasants was estimated based on data from release and recapture points.

Five males and seven females were released with radio transmitters in Tochigi Prefectural Citizen's Park in Yaita City $\left(36^{\circ} 50^{\prime} \mathrm{N}, 139^{\circ} 50^{\prime} \mathrm{E}, 400 \sim 1,200 \mathrm{~m}\right.$ in altitude). Its total area is $1,500 \mathrm{ha}$, which is mostly occupied by a coniferous plantation of cedar Cryptomeria japonica (36.4\%), cypress Chamaecyparis obtusa (27.9\%), larch Larix kaempferi $(8.2 \%)$ and others $(2.6 \%)$, but $23.4 \%$ of the area is a secondary natural forest area that includes oaks Quercus serrata and $Q$. mongolica, hornbeam Carpinus laxiflola, and pepper trees Clethra barbinervis. There were few bushes in the plantation area due to regular thinning by park workers, but the Japanese spindle tree Eunymus sieboldianus, wild smilax Smilax china, bramble Rubus palmatus, Hydrangea Hydrangea hitra, and bamboo grasses Sasa nipponica and Pleioblastus chino grew as lower story or undergrowth within the secondary forest.

All birds being provided to radio tracking research were raised by breeders in Tochigi

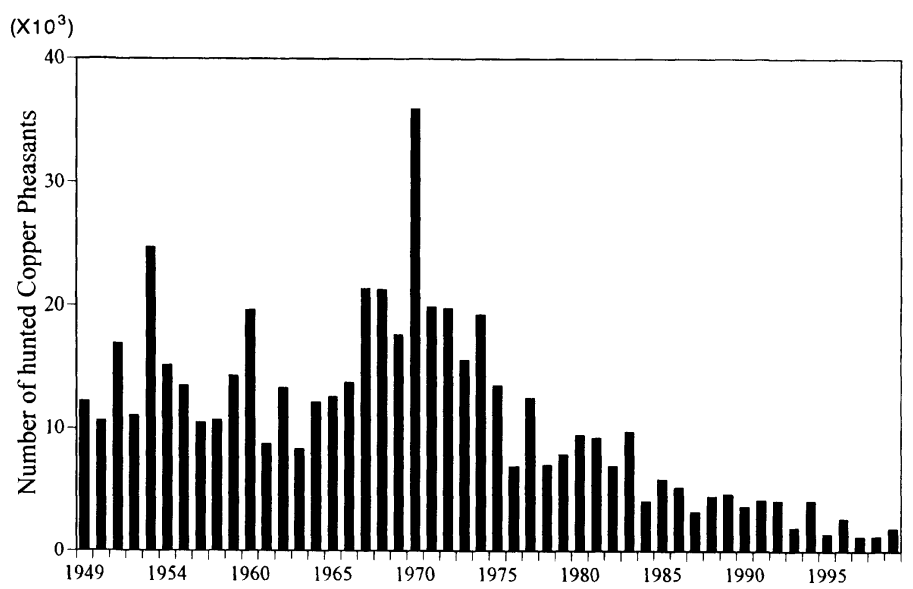

Fig. 2. Annual trends in the number of hunted Copper Pheasants in Tochigi prefecture. 
prefecture. The birds, which were almost all less than one year old, were reared in juvenile group, not by female parents as in the wild. They were kept in a wide cage (about 200 $\mathrm{m}^{2}$ in area) for at least two weeks before being released. Mean body weights were 915.0 \pm 40.3 (S. E.) g for males $(n=5)$ and $735.0 \pm 54.4$ (S. E.) $\mathrm{g}$ for females $(n=7)$, which were a little lighter than those of adults in the wild (e.g. 943-1,348 $\mathrm{g}$ for males and 745$1,000 \mathrm{~g}$ for females from Kiyosu 1978).

Transmitters, which were made by ATS and Architech Co. Ltd., were attached to the backs of birds with harness belts. They weighed $8-12 \mathrm{~g}$, or $0.8-2.2 \%$ of the body weight of the birds. Two males and 3 females were released in November 1997, a male and a female each in May and June 1998 and a male and 2 females in December 1998. Radio tracking was conducted every day within a week after the release and then at 2- or 3-day intervals. The positions of birds were determined as an intersecting point at 3 directions indicated by Yagi antennas.

\section{Results}

Hunters captured only 36 birds, or $1.3 \%$ of all birds released from 1989 to 1997. Most of them were shot during the hunting season just after being released; only nine birds $(0.3 \%)$ were captured beyond two hunting seasons. We have not found a significant relationship between success ratio and the number of recaptured pheasants $(r=-0.175$, $p>0.50$, Fig. 3). The recapture rates of released pheasants in each year are showed in Figure 4. They significantly fluctuated among years $\left(\chi^{2}=21.73, p<0.05\right)$.

Localities of release and recapture spots are shown in Figure 5. The longest distance between release and capture spots was $86.6 \mathrm{~km}$, where the bird was recaptured 654 days after the release. The mean distance was $14.6 \pm 4.7$ (S.E.) $\mathrm{km}$. There was a significant relationship between the period and distance in which released birds were captured $(t=$ $3.299, p<0.01)$.

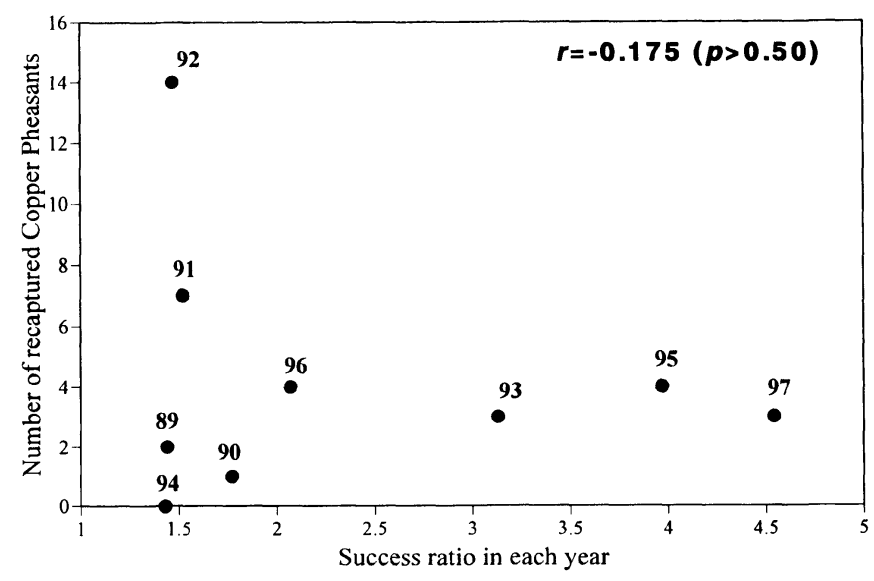

Fig. 3. Relation between numbers of recaptured Copper Pheasants and success ratio from 1989 to 1997 in Tochigi prefecture. Figures in graph show years. 


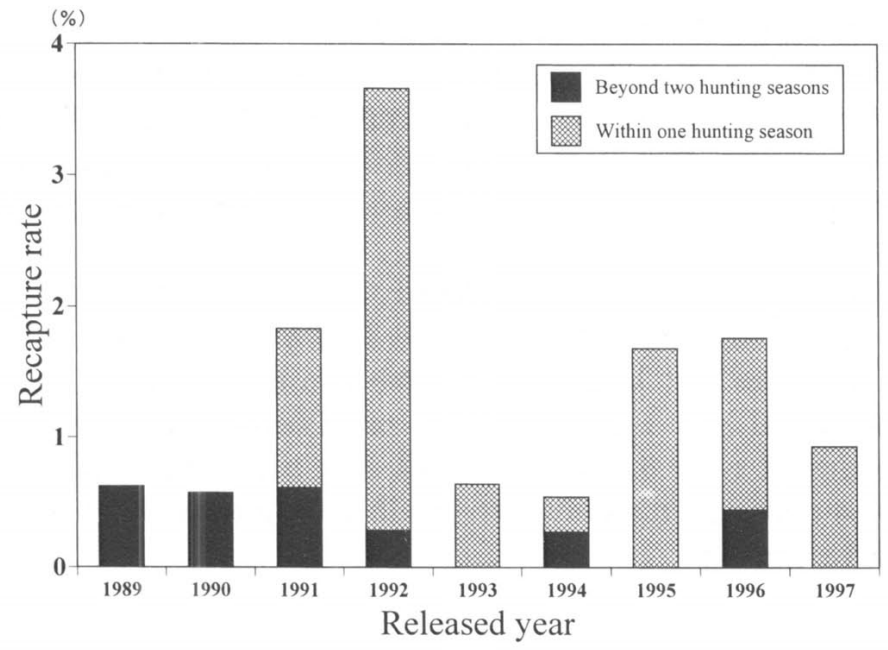

Fig. 4. Trends in recapture rates of released Copper Pheasants by year.

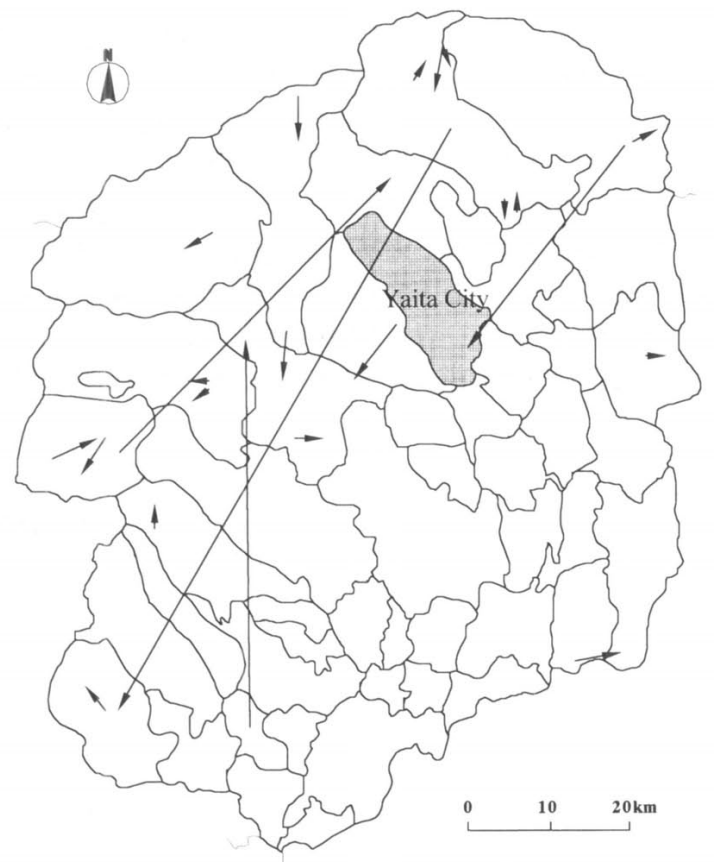

Fig. 5. Localities of released and recaptured spots in Tochigi Prefecture. Routes and tops of arrows show the released and recaptured places, respectively.

Of the 12 pheasants with transmitters released in Tochigi Prefectural Citizen's Park, 8 were recovered 1-39 days after the release (Fig. 6). Six of the transmitters were found among scattered feathers of the pheasants. Thus we could conclude that they were killed 


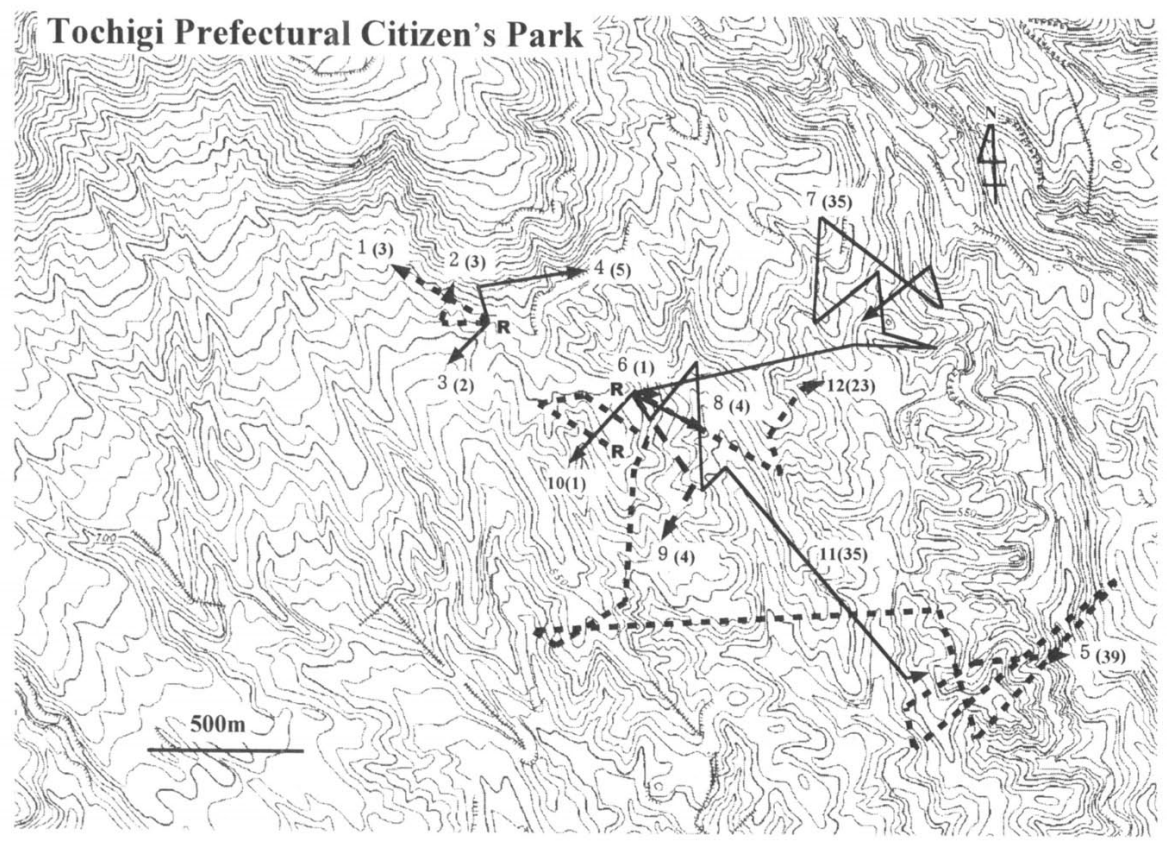

Fig. 6. Radio tracking trace data of released Copper Pheasants in Tochigi Prefectural Citizen's Park. The solid lines show the routes of males and the broken lines show females. Three released places are showed with the symbol " $R$ ". The arrow tips show where transmitters were found, or the last point where contact with transmitters was made. Figures show individual identification codes, and figures in parentheses show the last dates.

and predators took off the transmitters. Two others were found with carcasses. One of them was a headless carcass under ground and the other was not disturbed. The longevity of released birds with transmitters was $11.4 \pm 5.6$ (S.E.) days $(n=8)$. The remaining four transmitters could not be located.

All four birds that had survived more than 20 days had moved down along the stream soon after the release. One female (No. 5) had moved about $1,700 \mathrm{~m}$ from the release point by 20 days after the release. It settled near that place at that time, but the transmitter and many feathers were found 39 days after release. One male (No. 7) had moved $800 \mathrm{~m}$ by 6 days after release, and settled near that place for about a month, but the condition of the pulse suddenly changed on the 35th day, and the transmitter could not be found. Another male (No. 11) was found dead in a forest about $1,400 \mathrm{~m}$ from the release point on the 35th day after release. Another female (No. 12) had moved $500 \mathrm{~m}$ by 23 days after the release, but the transmitter could not be located after that (Fig. 6).

\section{Discussion}

We obtained the information about the recapture rate from three other prefectures. The rate of Gunma prefecture (3.0\% in 1999 and 2000, Gunma Prefecture Office, pers. comm.) was higher than that of Tochigi prefecture, but those of Saitama prefecture $(0.1 \%$ 
between 1995 and 2000, Saitama branch of Dainippon Ryoyukai, pers. comm.) and Yamaguchi prefecture (0.1\% between 1994 and 2000, Yamaguchi branch of Dainippon Ryoyukai, pers. comm.) were somewhat lower than Tochigi.

Our results indicate that these recapture rates do not necessarily relate with the success ratio of hunting and the number of birds released annually. Three factors were assumed to affect these recapture rates. The first is that many released birds might have survived but were not recaptured. Because captive-bred Copper Pheasants have been released in refuges or hunting prohibited areas, individuals that move out to hunting areas are extremely rare. However, the fact that Copper Pheasants released in refuge areas in Tochigi prefecture had been recaptured in hunting areas showed that they could easily move in areas adjacent to release points just after release, and sometimes to far areas after long periods.

According to our radio-tracking data, released Copper Pheasants quickly moved along the stream near the release point. Thus, the release of the Copper Pheasants into refuge areas did not necessarily restore the natural populations in those areas. One reason why released pheasants may have moved soon after release is due to the aggressive territory defense behavior of the pheasant (Yamashina 1976, Maru 1997), in which resident individuals in protected areas might exclude new immigrants.

Second, the number of hunters who tried to capture Copper Pheasants has rapidly declined recently (Dainippon Ryoyukai, pers. comm.). In addition, the recapture information from local governments is just based on the declaration of the hunters themselves. Therefore, the recapture data might be underestimated because hunters who have captured released pheasants have not always reported to the local government. Though the number of hunters in Tochigi prefecture decreased by $31.9 \%$ from 6,414 in 1990 to 4,365 in 1997 , the recapture rates during these periods did not decrease. This appeared that the number of hunters who declared in each year did not rapidly decrease.

The third cause is the high mortality of released individuals. Our radio-tracking research for released pheasants showed very short longevity for them. Radio tracking surveys on released Copper Pheasants were conducted in the same field as ours in the past (Masubuchi \& Atsumi 1975, Atsumi 1976, Tsubuku \& Matsumoto 1991, Matsumoto \& Kato 1992). Masubuchi \& Atsumi (1975) and Atsumi (1976) reported that four males (seven or eight months old) and one female (18 months old) were released in November to December, and tracked for only three to six days. The female was apparently killed by a fox on the fifth day after the release, but the fate of rest is still unknown.

Tsubuku \& Matsumoto (1991) and Matsumoto \& Kato (1992) reported that four males and one female were tracked with transmitters for two years, and four were found as carcasses within two weeks and the fifth one was lost on the 26th day after the release. Their longevity was $11.2 \pm 4.8$ (S.E.) days $(n=5)$, which was nearly the same as our result. One of the main purposes of release to the refuge area is that released pheasants at least survive until the breeding season in the wild. Therefore, our and other researchers' results indicate that most released Copper Pheasants die before achieving the purpose of release.

Predators such as red foxes, raccoon dogs and martens also cannot be hunted in 
refuge areas, so released pheasants might have a high predation risk there. Fujimaki (2000) suggested that main cause of the recent decline of the Hazel Grouse Bonasa bonasia in Hokkaido could be an increase of predators, especially red fox. If the main causes of rapid decrease of a natural population are an increase of predators and a high mortality of chicks caused by predators, some sort of predator control program might be necessary, such as in the Grey Partridge restoration project in England (Aebischer 1997).

The mortality of released Green Pheasants, Phasianus colchicus, is also reported to be high (Dainippon Ryoyukai 1986). It reported that the release time and places should depend on the purpose of release, and recommended that the male Green Pheasants should be released just before the beginning of the hunting season and in hunting areas, not in refuges for game hunting. On the other hand, female pheasants are ideally released just before the breeding season in order to restore and sustain natural populations. Therefore, if the aim of Copper Pheasants release is also the restoration of natural populations in the wild, the females should be released into protected area just before the breeding season.

The mating system of Copper Pheasants in the wild is still unknown. In captivity, males sometimes injure and kill females during copulation (Yamashina 1976). But, we frequently found one male that tightly guarded only one female in the breeding season in the wild (Kawaji in prep.). A lot of males in hunting areas would be decreased by hunting and the sex ratio would be biased toward females. Thus, local governments should expand the seasonal hunting-prohibited areas only for the Copper Pheasant, especially in areas that have showed a decline in harvest. Only male Copper Pheasants should be released into hunting areas just before the beginning of the hunting season for hunters. If this is done, the resident old males would have a high probability of surviving, and the natural populations in hunting areas will be able to recover.

\section{Acknowledgments}

We wish to thank Mr. Sei-ichi Suzuki and the staff of the Tochigi Prefectural Citizen's Park Management Office for their assistance and encouragement of our research in that park. We would also like to thank Dr. Masahiko Takeuchi for helping us with our radio tracking work and giving us useful suggestion, and the Yaita branch of the Japanese Hunting Association (Dainippon Ryoyukai) for providing us with captive-bred Copper Pheasants for our research. We are also grateful to Dr. Eiji Kitahara for his critical comments regarding the manuscript.

\section{References}

Aebischer, N. J. 1997. Gamebirds: Management of the Grey Partridge in Britain. Conservational Biology, Series 8: 131-151. Chapman and Hall (Kluwer).

Atsumi, H. 1976. Yamadori no koudou tsuiseki no telemetry (Telemetry for the released Copper Pheasants). Annual report of Tochigi Prefectural Citizen's Park (2): 6-9. (In Japanese)

Dainippon Ryoyukai. 1986. Kiji no hocho kouka ni kansuru kisoteki kenkyu houkokusho (Report on fundamental research for the evaluation of release of Green Pheasants). Dainippon Ryoyukai, Tokyo. (In Japanese).

Environmental Agency. 1975. Choju Kankei Tokei (Wildlife Statistics in 1973). Environmental Agency. (In Japanese) 
Environmental Agency. 2000. Choju Kankei Tokei (Wildlife Statistics in 1998). Environmental Agency. (In Japanese)

Fujimaki, Y. 2000. Recent Hazel Grouse Bonasa bonasia population decline in Hokkaido, Japan. Japanese Journal of Ornithology 48: 281-284.

Fuller, R. A. \& Garson, P. J. 2000. Pheasants. Status Survey and Conservation Action Plan 2000-2004. WPA/Bird Life/SSC Pheasant Specialist Group. IUCN, Gland, Switzerland and Cambridge, UK and the World Pheasant Association, Reading, UK.

Hokkaido Institute of Environmental Science. 1998. Yamadori bunpu chosa houkokusyo (Research report of the distribution of the Copper Pheasant), Hokkaido Institute of Environmental Science, Sapporo. (In Japanese)

Kawaji, N. 1993. Hokkaido ni okeru yamadori (The Copper Pheasants in Hokkaido). Hoppo Ringyo 43(2): 3233. (In Japanese)

Kiyosu, Y. 1978. Nihon Chorui Daizukan II, revised ed. (Birds of Japan II). Koudansha, Tokyo. (In Japanese) Leopold, A. 1961. Game Management. Charles Scribner's Sons, New York.

Maru, T. 1997. Yamadori (The Copper Pheasant). The Encyclopedia of Animals in Japan, 4 Birds II (ed. by H. Higuchi, H. Morioka and S. Yamagishi): 14-15. Heibonsha, Tokyo. (In Japanese)

Masubuchi, S. \& Atsumi, H. 1975. Yamadori no koudoutsuiseki no telemetry. (Telemetry for the released Copper Pheasants). Annual report of Tochigi Prefectural Citizen's Park (1): 16-22. (In Japanese)

Matsumoto, I. \& Kato, T. 1992. Radio telemetry ni yoru koudoutsuiseki chosa (Radio tracking of the released Copper Pheasants). Annual report of Tochigi Prefectural Citizen's Park (18): 3-5. (In Japanese)

Tsubuku, T. \& Matsumoto, I. 1991. Radio telemetry ni yoru koudoutsuiseki chosa (Radio tracking of the released Copper Pheasants). Annual report of Tochigi Prefectural Citizen's Park (17): 2-4. (In Japanese)

Yamashina, Y. 1976. Notes on the Japanese Copper Pheasant Phasianus soemmerringii. The World Pheasant Association Journal (1975-1976): 23-42.

\section{栃木県において野外個体群の回復のために放鳥されたヤマドリの運命}

栃木県において，野外個体群の回復のために放鳥されたヤマドリ養殖個体の運命について， 狩猟者からの足環の回収報告結果およびラジオトラッキング調査から調べた。1989年から 1997 年にかけて放鳥されたオスのヤマドリのうち, 放鳥時に装着された足環が狩猟者により回 収されたのは $1.3 \%$ であった。また，回収された個体のうちのほとんどが，放鳥されたのと同 じ狩猟期に得られたあのであり， 2 年以上生存した個体は，わずか $0.3 \% に$ 過ぎなかった。栃木 県県民の森で行った放鳥ヤマドリに対するラジオトラッキング調査の結果, 短い寿命 (平均 11.4 日）であることがわかった。栃木県で放鳥した場所と足環が回収された場所との間の直線 距離を算出したところ, それほど大きな值は得られなかったが (平均で $14.6 \mathrm{~km}$ ), $40 \mathrm{~km}$ 以上 移動したと思われる個体が複数個体存在し, 最高で $87 \mathrm{~km}$ 移動した個体もあった。今回の結果 から, 現在の放鳥方法では放鳥の所期の目的を達成することは困難と思われる。そこで，オス の放鳥場所をこれまでの鳥獣保護区から可猟区にすることやメスを繁殖期直前に放鳥するなど の改善策を提言する。

川路則友：森林総合研究所野生動物研究領域.テ305-8687 茨城県つくば市松の里 1. E-mail: kawajin@ffpri.affrc.go.jp

山口恭弘：農業技術研究機構中央農業総合研究センター耕地環境部鳥獣害研究室. 8666 茨城県つくば市観音台 3-1-1. E-mail: yamay@affrc.go.jp

矢野幸弘：栃木県県民の森管理事務所. ○329-2514 栃木県矢板市長井 2927. (現所属：栃木 県造林課. ₹320-8501 栃木県宇都宮市塙田 1-1-20) 